\title{
Kuzbass adapting to the global energy transition
}

\author{
Yuri Fridman ${ }^{1,2}$, Galina Rechko, ${ }^{1,2}$, Ekaterina Loginova $^{1}$, and Aleksandr Pimonov ${ }^{1,2}$ \\ ${ }^{1}$ Institute of Economics and Industrial Engineering of the Siberian Branch of the Russian Academy of \\ Sciences, 630090 Novosibirsk, 17 Acad. Lavrentyev Av., Russian Federation \\ ${ }^{2}$ T.F. Gorbachev Kuzbass State Technical University, 650000 Kemerovo, 28 Vesennyaya st., Russian \\ Federation
}

\begin{abstract}
The world energy system has entered the so-called energy transition stage, with decarbonization and the fight against climate change as drivers for change. This event may pose many grave dangers for the Russian coal industry and commodity-rich regions of the country, whose economy is based on coal mining. The authors rely on the research into the strategic development of Kuzbass, Russia's major coal center, and discuss whether the state should actively participate in ensuring that the region adjusts to the terms of the energy transition.
\end{abstract}

\section{Introduction}

The global energy system has entered a period of fundamental transformations. The ongoing change has become another (already the fourth one) energy transition [1] from one dominant energy source to another. However, unlike its three predecessors, the driver of change is now "not so much the economic attractiveness of new energy sources but a qualitatively new factor: decarbonization and the fight against global climate change" [2]. It means that the world's fuel and energy balance will continue to diversify towards unconventional renewable energy sources with the use of carbon-free or low-carbon technologies. On the other hand, there is a political aspect to the new energy transition, which has to do with the need to ensure energy security for those nations where traditional energy resources are scarce or that possess the reserves the extensive use of which is discouraged (like coal) (e.g., see [3-4]).

\section{Characteristic of the work}

It is reasonable to assume that the most radical changes within the initiated energy transition will affect the coal ranking in the structure of the world electricity generation, sector responsible for the most substantial consumption of this fossil fuel. Russia is currently the third biggest coal exporter in the global market. Should the world energy decarbonization scenario take even partial effect, it may trigger negative consequences for Russia's coal industry and threaten the coal business; which has not gone to seed in recent

\footnotetext{
*Corresponding author: yurifridman@mail.ru
} 
years - amid a stagnant domestic market, influenced by price disparities favoring gas, and under natural processes of economic globalization - only thanks to exports. Environmental regulations limiting the use of coal especially relevant for Europe, improved economic energy efficiency in major coal-importing countries, low gas prices: these have become the main systemic factors behind a sharp and deep 2018-2020 drop in global coal prices. Such negative trends now lead to reduced investment in coal projects worldwide, making coal mining companies review their business models and find new mechanisms for sustainable development.

The decline in global demand for coal also endangers Russian regions with coal-based economies. Kemerovo Oblast - Kuzbass, producing about $60 \%$ of the country's coal, expectedly leads the "risk group." Hence, it is imperative to revise the Russian Federation's state policy in respect of coal territories, which should be naturally supported by amending the development models for regions rich in mineral resource regions and designing workable mechanisms to fulfill their strategic guidelines (e.g., see [5-9]).

Economic growth in Kuzbass has always been supported by the government, both directly and indirectly. The forms and instruments have changed at times throughout its history, despite two characteristics remaining the same: the support's ever-present nature and decisive role. It was not a manifestation of state altruism but state pragmatism (patriotism, even).

Over the last two decades, however, the state policy towards Kemerovo Oblast has been incomprehensible at best. Before and after the program to support Kuzbass as part of the Russian coal industry restructuring until 2016, the federal government did not arrange another full-scale development project. It solved several essential problems for Kuzbass (both the coal basin and the region):

- $\quad$ reorganized and restored coal enterprises unable to function in an open market;

- $\quad$ aided in transferring coal assets to effective business owners;

- $\quad$ preserved the regional coal industry training school;

- multiplied private investment performance as the investors had to neither devote funds to personnel training nor solve various social and environmental problems;

- $\quad$ ensured that private investment flows into new mining technologies and transport infrastructure to create industry and technology clusters, which increased the return on investment and spurred its growth.

The Russian government spent a total of $\$ 13.2$ billion on restructuring the national coal industry between 1994 and 2016. Tax revenues plus investment in the industry and infrastructure projects recouped this sum (in 1999-2016 alone, budgets at all levels received \$15.6 billion) [10, p. 31]. In 1999-2016, coal enterprises invested \$24.5 billion in fixed assets, making a full retrofit in the industry possible (425 million tons of production capacities put into operation) [10, p. 27]. Understandably, a significant portion of these funds was allocated to Kuzbass. Although the government (and regional authorities, to a greater extent), while investing such monstrous amounts, somehow "forgot" to establish the fundamental rule for business: everything shall be for the people and their benefit only.

In 2018, when coal exports brought high earnings, the state attempted to formulate new ambitious development plans for the coal industry in Russia and Kuzbass in particular. But the collapse of coal prices and the EU's decision to phase-out this fuel in the next 10-15 years changed the situation drastically. In effect, now the region cannot count on growing coal production as a driver for economic growth.

Given the circumstances, a plan proposed by the federal authorities to establish a cultural cluster (one of the four in Russia), a large science and education center, and other structures in Kemerovo Oblast appears to be a compensation for the unclear policy towards the region and does not recognize its competitive advantages. Although today, perhaps more than ever, Kuzbass needs a system of practical solutions and measures adequate to the 
situation at hand, which would ensure the region's security and gradual transformation in the face of the new energy transition.

\section{Conclusion}

As we see it, the strategic goals and objectives for Kemerovo Oblast should focus on improving the quality of life and raising living standards. Economic policy should rest upon a comprehensive approach and interregional cooperation. To address pressing issues in the current environment, it is necessary to acquire fundamentally new knowledge about the nature and processes of development and exploitation of Kuzbass resource potential. It is crucial to create a knowledge base system to help generate options for solving economic and other problems.

In parallel, or better yet ahead of time, the government must adopt the following new management practices:

- $\quad$ stimulate business owners to invest in innovation and human capital;

- apply fresh approaches to environmental management when the purpose of environmental protection is to restore the disrupted biosphere;

- introduce professional and public examination of projects related to the use of Kuzbass natural resources at all stages, from idea to execution;

- change tax administration to give the region peace of mind about its future;

- take full advantage of possibly integrating Kemerovo Oblast with neighboring regions, especially in innovation, science, education, and medicine;

Such an approach will enable Kuzbass to actively influence Siberia's development strategy while maintaining its status as an important economic center.

\section{Acknowledgement}

The publication is prepared within the priority XI.174. (project No. XI.174.1.1. "Economy of Siberia and its Regions Among the External and Internal Challenges and Threats: Methodology, Trends, Forecasts", No. AAAA-A17-117022250133-9) according to the research plan of the IEIE SB RAS.

\section{References}

1. V. Smil, Energy Transitions: History, Requirements, Prospects (Praeger, Santa Barbara, 2010).

2. Global and Russian Energy Outlook 2019 / ed. A.A. Makarov, T.A. Mitrova, V.A. Kulagin; ERI RAS - Moscow School of Management SKOLKOVO (Moscow, 2019).

3. B. K. Sovacool, Conceptualizing the Temporal Dynamics of Energy Transitions, Energy Research \& Social Science, 13, 202-203 (2016).

4. B. Ricketts (ed.), Coal Industry across Europe. 6th edition (EUROCOAL: European Association for Coal and Lignite, 2017).

5. Yu. Fridman, G. Rechko, E. Loginova, Journal of Mining Science, 51:5, 924 (2015).

6. Yu. Fridman, G. Rechko, A. Pimonov, Regional Research of Russia, 7:4, 333 (2017).

7. Yu. Fridman, E. Loginova, G. Rechko, E3S Web of Conferences, 134, 03002 (2019).

8. V. Kondrat"ev, World Economy \& International Relations, 60:1, 41 (2016).

9. V. Kryukov, A. Sevastyanova, A. Tokarev \& V. Shmat, Economy of region, 13:1, 93 (2017). 
10. G. Krasnyansky, A. Sarychev, A. Skryl', Economic crises and coal of Russia (National University of Science and Technology "MISiS" Publ., Moscow, 2017). 